\title{
Redução do número de espermatozóides por fêmea suína inseminada por ano*
}

\section{PAULO EDUARDO BENNEMANN}

\author{
Fernando Pandolfo Bortolozzo (Orientador-UFRGS) \\ Ivo Wentz (Co-Orientador - UFRGS) \\ Mari Lourdes Bernardi (Co-Orientadora - UFRGS)
}

Banca: Ilmo Wentz (UFSM), Fabiane Mendonça Ferreira (UNICRUZ), Rui Fernando Félix Lopez (UFRGS)

\begin{abstract}
Na inseminação artificial de suínos, são utilizados de 9 a 12 bilhões de espermatozóides por fêmea inseminada. A utilização de menor número de espermatozóides, sem interferir na performance reprodutiva das fêmeas, poderia otimizar o uso dos machos e reduzir os custos de inseminação. Esta tese foi dividida em três experimentos para avaliar o efeito da redução do número de espermatozóides por fêmea inseminada com a técnica tradicional ou intra-uterina. No experimento 1 foram utilizadas 218 leitoas Camborough $22^{\circledR}$ inseminadas em três intervalos antes da ovulação (0-12, 13-23 e 24-30 h), com doses inseminantes (DIs) contendo 1,5 bilhão de espermatozóides e armazenadas por 0-48 h ou 96-120 h. As leitoas receberam uma única inseminação. As fêmeas foram abatidas aos 30,8 +3,7 dias de gestação para contagem do número de corpos lúteos (CL) e embriões totais (ET). A taxa de prenhez (TPr) foi influenciada pelo intervalo inseminação-ovulação (IAOV) quando o sêmen foi armazenado por $96-120 \mathrm{~h}(\mathrm{P}<0,05)$. Da mesma forma, a interação tempo de armazenamento do sêmen e o intervalo IAOV afetou $(\mathrm{P}<0,05) \mathrm{o}$ ET e a sobrevivência embrionária (SE). Quando o período de armazenamento do sêmen foi de $120 \mathrm{~h}$ e o intervalo IAOV de 24-30h, foi observada redução no ET e na SE. No experimento 2 foi avaliado o efeito do intervalo IAOV e do número de espermatozóides na DI em fêmeas submetidas à inseminação intra-uterina (IAU). Foram utilizadas 66 matrizes pluríparas Camborough $22^{\circledR}$. As fêmeas foram distribuídas em quatro tratamentos (doses de 1 ou 2 bilhões de espermatozóides diluídos em 60 ml e intervalo IAOV de 0-24 e 25-36 h). As fêmeas receberam uma única IAU. No momento da inseminação, não foi observado refluxo de sêmen. A passagem do cateter pela cérvix foi possível em todas as fêmeas. Foi observada presença de sangue em 1,7\% das fêmeas. Aos 31ะ4,3 dias de gestação, as fêmeas foram abatidas para contagem dos CL e ET. A TPr e a SE não foram afetadas pelo número de espermatozóides ou pelo intervalo IAOV. O ET não foi influenciado pelo número de espermatozóides, mas foi reduzido para o intervalo IAOV de 25-36 h comparado a 0-24h $(\mathrm{P}<0,05)$. No experimento 3 foram utilizadas 298 fêmeas Camborough $22^{\circledR}$ com o objetivo de comparar o desempenho reprodutivo de fêmeas submetidas à IAU e a inseminação tradicional. As fêmeas foram distribuídas em dois tratamentos: T1: IAU com DIs contendo 0,5 bilhão de espermatozóides em um volume total de $20 \mathrm{ml}$; T2: inseminação tradicional com DIs contendo 3,0 bilhões de espermatozóides em um volume total de 90 ml. As fêmeas receberam múltiplas inseminações. Foi possível a realização da IAU em 98,1\% das fêmeas. A presença de sangue, na extremidade do cateter ou espiral da pipeta de IAU, foi observada em $8,4 \%$ das fêmeas. A TPr e taxa de parto ajustada não diferiram entre os tratamentos. No entanto, o tamanho da leitegada foi menor $(\mathrm{P}<0,05)$ na IAU quando comparado à tradicional. Na inseminação artificial tradicional, em leitoas, é possível utilizar 1,5 bilhão de espermatozóides sem que a TPr, ET e SE sejam comprometidas. Para a IAU, a utilização de 1 bilhão de espermatozóides não compromete o desempenho reprodutivo.
\end{abstract}

Descritores: inseminação artificial, inseminação intra-uterina, redução do número de espermatozóides.

Apresentada: 18 março 2005

*Tese de Doutorado n.56 (Especialidade: Fisiopatologia da Reprodução). 79f. Programa de Pós-graduação em Ciências Veterinárias [www.ufrgs.br/ ppgcv], Faculdade de Veterinária - UFRGS, Porto Alegre/RS. CORRESPONDÊNCIA: P.E. Bennemann [peb.edu@ig.com.br] \& F.P. Bortolozzo [fpbortol@ufrgs.br]. 


\title{
Sperm reduction per swine female inseminated per year ${ }^{* *}$
}

\author{
PAULO EDUARDO BENNEMANN
}

\author{
Fernando Pandolfo Bortolozzo (Adviser - UFRGS) \\ Ivo Wentz (Co-Adviser - UFRGS) \\ Mari Lourdes Bernardi (Co-Adviser - UFRGS)
}

Committee: Ilmo Wentz (UFSM), Fabiane Mendonça Ferreira (UNICRUZ), Rui Fernando Félix Lopez (UFRGS)

In artificial insemination of swine, 9 to 12 billion sperm are used for female inseminated. Using a low sperm number, without affecting the reproductive performance of female, could optimize the use of males and reduce the costs of insemination. This thesis was divided in three experiments to evaluate the effect of the reduction in sperm number per female inseminated with the traditional or intrauterine technique. In experiment 1, 218 Camborough $22^{\circledR}$ gilts were inseminated at three artificialinsemination intervals before ovulation (0-12, 13-23 and 24-30 h) with 1.5 billion semen dose (SD) stored for 0-48 h or 96-120 h. Gilts were inseminated once. Pregnant gilts were slaughtered at 30.8 \pm 3.7 days of gestation and corpora lutea (CL) and total embryos (TE) were counted. Pregnancy rate(PR) was affected by artificial insemination-ovulation (AIOV) interval when semen doses were stored for $96-120 \mathrm{~h}(\mathrm{P}<0.05)$. Similarly, storage time and AIOV interval interaction affected $(\mathrm{P}<0.05)$ the TE and embryo survival (ES). It was observed a reduction in TE and ES when semen was stored up to $120 \mathrm{~h}$ and AIOV interval was higher than 24-30 h. In experiment 2 it was evaluated the effects of AIOV interval and SD on sows submitted to intrauterine insemination (IUI). Sixty six pluriparous sows Camborough $22^{\circledR}$ were grouped in four treatments (1 or 2 billions sperm dose diluted in a total volume of $60 \mathrm{ml}$ and AIOV interval of 0-24 or 25-36 h). All sows were inseminated once. Semen backflow during insemination did not occur. It was possible to insert the flexible catheter through the cervix in all sows. The presence of blood in the catheter tip was observed in $1.7 \%$ of sows. At $31.7 \pm 4.3$ days of gestation, sows were slaughtered and CL and TE were counted. The PR and ES were not affected by sperm number or AIOV interval. TE was not affected by sperm numbers, but it was reduced when AIOV interval was $25-36 \mathrm{~h}$ in comparison to $0-24 \mathrm{~h}(\mathrm{P}<0.05)$. In experiment 3,298 sows Camborough $22^{\circledR}$ were used. The aim of this study was to compare the reproductive performance of sows submitted to IUI or traditional artificial insemination. The sows were distributed in two treatments: T1 - IUI performed with 0.5 billion sperm doses in a total volume of $20 \mathrm{ml}$; T2 traditional insemination performed with 3.0 billions sperm doses in a total volume of $90 \mathrm{ml}$. Sows received several inseminations. It was possible to perform the IUI in $98.1 \%$ of sows. The presence of blood on the catheter tip or pipette was observed in $8.4 \%$ of IUI sows. PR and adjusted farrowing rate did not differ between treatments. However, litter size was lower $(\mathrm{P}<0.05)$ in IUI than in traditional insemination. In gilts, traditional insemination can be performed with 1.5 billion sperm without compromising their PR, TE and ES. For IUI is possible to utilize 1 billion sperm without affecting the reproductive performance.

Key words: artificial insemination, intra-uterine insemination, sperm number reduction.

Presented: 18 March 2005

\footnotetext{
${ }^{* * *}$ Doctoral Dissertation \#56 (Field: Theriogenology). 79p. Graduated Program in Veterinary Sciences [www.ufrgs.br/ppgcv], Faculdade de Veterinária, Universidade Federal do Rio Grande do Sul (UFRGS), Porto Alegre/Brazil. CORRESPONDENCE: P.E. Bennemann [peb.edu@ig.com.br] \& F.P. Bortolozzo [fpbortol@ufrgs.br].
} 